\title{
Tause helseplager
}

\begin{abstract}
Mange kvinner som er omskåret, har helseplager de tier om, også på legens kontor. For å oppdage disse plagene er det viktig at legen stiller nødvendige spørsmål og undersøker om det kan være sammenheng mellom plagen pasienten søker lege for og omskjæringen, som ikke blir nevnt.
\end{abstract}

På et legesenter et sted i Groruddalen en høstlig formiddag i oktober. I anledning en nær forestående forskningskonferanse i Kenya har jeg på kort varsel fått time for vaksinering. Mens jeg venter på at legen finner frem nødvendig utstyr, gjør jeg det jeg antar en del pasienter tyr til i påvente av at alt blir klart - jeg forsøker meg på litt løst småprat. «Du skjønner, jeg skal til Nairobi,» begynner jeg. «På en forskningskonferanse om omskjæring av jenter.» «Ja ha,» svarer legen og fortsetter: «l løpet av alle de årene jeg har jobbet på dette legesenteret, har jeg kun sett én kvinne som har vært utsatt for det, og det så ikke bra ut.» Kun én kvinne som har søkt hjelp på grunn av omskjæringsrelaterte plager? Med tanke på at dette er et legesenter i Groruddalen, et område i Oslo der en betydelig andel av innbyggerne har etnisk minoritetsbakgrunn, er tallet urovekkende lavt.

Legens erfaring støttes imidlertid av studier som viser at mange omskårne kvinner i liten grad tar initiativ til å snakke med lege om inngrepet (1). Flere er også nølende til gynekologisk undersøkelse (2). Dette til tross for at andre studier kan dokumentere at kvinner og jenter som er omskåret, ikke sjelden har fått helsemessige konsekvenser som følge av inngrepet (3). Mange omskårne jenter og kvinner har med andre ord plager og komplikasjoner de i liten grad snakker med andre om, heller ikke legen.

Som en del av et forskningsprosjekt ved Nasjonalt kunnskapssenter om vold og traumatisk stress (NKVTS) har jeg fått delta i helseundervisning om omskjæring, kropp og seksualitet som skolehelsetjenesten på en videregående skole i Oslo tilbyr jenter og gutter som kommer fra land der omskjæring av jenter er utbredt. Her blir elevene delt inn i jente- og guttegrupper som møtes en gang i uken over fire uker. I gruppene får elevene mulighet til å diskutere temaer som pubertet, seksualitet, samliv og fødsler knyttet opp mot omskjæring. I norsk sammenheng fremstår ikke sjelden den offentlige debatten som en litt brå og høylytt kontrast til utsatte jenter og kvinners mer stillferdige tilnærming. I tillegg råder det en oppfatning blant forskere og praktikere om at omskjæring representerer et tabu som berørte jenter og kvinner er ubekvemme med å snakke om. I forkant av gruppemøtene var jeg derfor spent på hvordan stemningen ville være og om jentene ville engasjere seg i diskusjonen. Ikke sjelden var stemningen til å begynne med noe avventende, men en trygg og erfaren helsesøster flettet humor og uhøytidelighet inn i nøktern helseundervisning. Spørsmålene kom litt om litt: Fører infibulering til at utsatte jenter får sterkere menstruasjonssmerter enn andre jenter? Er det mulig å få infibulering åpnet gjennom helsevesenet? Kan man velge å åpne litt om gangen, slik at det skjer gradvis over tid? Hva skjer når man skal føde? Er det straffbart å være omskåret i Norge? Gruppene gir også rom for diskusjon. Hvem er omskjæring et problem for? Om man selv er fornøyd med å være omskåret, burde det vel ikke være noe problem for andre? Er det greit at jenter blir «litt» omskåret?

Erfaringene så langt er positive. Langt de fleste av jentene som deltar på det første møtet, kommer tilbake neste gang. Ikke sjelden dukker det opp jenter som har fătt høre om gruppene av klassevenninner og spør om de kan få bli med. Mange forteller at de har lært noe nytt om noe som angår dem og som de sjelden prater med andre om. Det blir derfor for enkelt å påstå at omskjæring er tabu. Tvert imot - i jentegruppene er jeg ved flere anledninger blitt forbauset over hvor liketilt jenter som selv har erfart inngrepet, snakker om det når betingelsene blir lagt til rette. Dette er kunnskap som kan overføres til legekontoret. I møte med jenter og kvinner som kommer fra land der omskjæring og infibulering er utbredt, kan det være god drahjelp om legen tar initiativ og stiller spørsmål om inngrepet. Kan hende er dette helt nødvendig for at kvinner i Groruddalen og andre steder skal bryte tausheten omkring plager de sliter med som følge av omskjæring nest gang de møter legen.

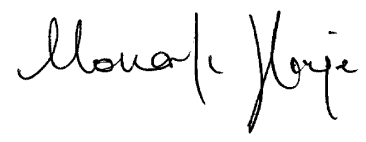

Litteratur

1. Vangen S, Johansen RE, Sundby J et al. Qualitative study of perinatal care experiences among Somali women and local health care professionals in Norway. Eur J Obstet Gynecol Reprod Biol 2004; 112: $29-35$.

2. Ahlberg N, Vangen S. Svangerskap og fødsel i det flerkulturelle Norge. Tidsskr Nor Lægeforen 2005; 125: $586-8$

3. WHO. Female genital mutilation and obstetric outcome: WHO collaborative study in six African countries. Lancet 2006; 367: 1835-41. 